\title{
Shall Library Schools Teach Administration?
}

Mr. Martin, assistant professor at the Graduate Library School, University of Chicago, treats the problems which confront library schools in one perplexing sector.

$\mathrm{T}_{\mathrm{s}}$ HE LIBRARY SCHOOLS are caught neatly in the pincers movement of those who call upon them to produce administrative leaders for the profession and those who contend that administrative leadership cannot be developed in the classroom. The schools meet this situation as they have the many little crises in their history: they camouflage by adding a few instructional units or changing a few course names and somehow elude the closing pincers. Then an armistice is declared in which the schools agree to produce administrative leaders at such time as the libraries will create positions for them and the libraries agree to create positions of administrative leadership at such time as the schools provide qualified candidates. This settlement enables the library schools to retain their tried-and-true methods for producing library technicians and clears the field for another pincers movement-this time, perhaps, from those who request that library school cataloging courses implant the principles of organizing and describing materials for use and from those who demand catalogers able to take over a job in a specific catalog department.

The net result of the minor tempest is to rock the library school instructor's boat. He doesn't know what the profession wants and he appears opinionated if he knows what he wants. The instructor's reaction is a counterpart of the school's defense: he steadies the boat and goes on paddling in the way that has carried him through course credits before.

The particular fate of the course in administration is that it often remains a course in library economy, which in practice means those techniques that are not treated elsewhere in the curriculum. Charging systems, order routines, statistical records, physical preparation and care of materials-these are sometimes the main content of the course. Obviously, such a course no more deserves the title "administration" than does the work in cataloging. Occasionally library school courses in administration have advanced to a second stage of development-that of library management. In this stage the elements of management-the topics or subjects with which a library manager deals in the course of a day-are emphasized. Careful attention to buildings and equipment exemplifies this level.

This paper advocates advancement into a third stage of development, in which the teaching of library administration is built around the administrative process.

The present quandary concerning instruction in library administration underlines the need for a new orientation. Small wonder that nonlibrarians are appointed to important positions in college and university libraries and elsewhere; small wonder that proposals are made in all seriousness 
for short programs in library schools to produce "ninety-day wonders" for executive positions-there is little in the customary curriculum that prepares for the judgment and responsibility of administration. The weakness of the first-year curriculum as a means for preparing library administrators becomes apparent when we think of recruiting young people with proved executive ability from among demobilized military personnel and subjecting them to the usual library school course.

\section{Content of Instruction}

Discussion of the question whether administration can be taught in a classroom can readily become sterile. It is like discussing whether logical thinking, civic responsibility, appreciation of beauty, or any of the other objectives of education over and above pure subject knowledge can be taught in a school. The answer is not a categorical "yes" or "no." Group instruction, if it goes beyond formalism to reality and if it is directed at individuals on the threshold of understanding in the field concerned, can initiate the student into the methods of analysis, the emotional reactions, and the responsibility of decision in such nonsubject areas. In a sense, the law school does not "teach" the lawyer how to convince a jury nor does the medical school "teach" the doctor a bedside manner, but in each case formal training facilitates later performance.

This viewpoint suggests an approach to instruction in library administration. If there are common situations faced in managing a department store, a factory, and a university library, and if common principles or proved modes of action can be formulated for resolving such situations, the teaching of library administration would have a foundation which would be sound and a viewpoint which would be refresh- ing. The course embodying it would then have a base broader than itself, in the same way that the course in book selection reaches out toward the psychology and sociology of reading or the course in reference toward broad subject fields.

Have the principles or modes of action in administration been formulated in a way that is useful in library school classrooms? Or are they buried as yet in such docu- . ments as David Lilienthal's TVA; Democracy on the March, Tom Girdler's autobiography, Boot Straps, and the annual reports of industrial corporations? One needs only mention such names as Gulick, Sorrell, Urwick, and Reeves in the area of general administration, and White, Mosher, and Gaus in the area of administration of public enterprises, to bring a considerable literature into focus. An interesting example of the use of generalized material for instruction in a specific service enterprise is the course in administration given by the U.S. Department of Agriculture for its junior executives. ${ }^{1}$

The concepts and methods developed in the new study of administration are not entirely theoretical nor are they necessarily alien to library operations. On the contrary, most of the encouraging recent developments in library administration have been derived from generalized methods growing out of management in quite diverse enterprises. Position classification, cost analysis, service ratings-these are out of the book of administration. Similarly, the developments that may prove useful to libraries in the immediate future are also part of the new formulation of administrative principles.

Understanding of administration should go beyond such specific devices to the administrative process itself. Administration

1 U.S. Department of Agriculture. Graduate
School. Administrative Management; Principles and School. Administrative Management; Principles and
Techniques. Lancaster, Pa., Lancaster Press, 1938. 
is not static but dynamic; it is concerned with an everchanging organization, not with a cross-sectional situation. The essential tasks of management in any enterprise are (I) to break down the total operation into specialized jobs filled by qualified individuals and (2) to coordinate specialized workers so that total production adds up to the objectives of the organization. The breakdown into specialized jobs is done in order to take advantage of differences in skill and temperament. Characteristic of its products are mass production and the assembly-line technique. Certainly, specialization of tasks plus coordination of specialists in industry has resulted in higher levels of skill, increased production, and reduced costs. American genius in this area has been a prime factor in the winning of the war to preserve democracy. When administration is viewed in this light one begins to see the foundations of a genuine course in library administration.

It may well be argued that such an analysis may apply to the General Motors Corporation but not to the average library. There is a certain justification in this, for most library units are so small that they cannot take advantage of specialization of tasks. Furthermore, since specialization is more applicable to the production of fabricated articles than to the rendering of service, this and other general administration concepts must be used with caution when applied to libraries. Yet one needs give only a moment's attention to the clerical-professional problem in libraries, for example, to recognize it as a problem in specialization of jobs, or to the "crisis in cataloging" to recognize it as a problem in administrative coordination rather than of professional competence, as has sometimes been assumed. The principles of administration do not apply as precisely to libraries as they do to industry, but they apply today far more than they did two decades ago and they are likely to apply still more two decades hence. Several analyses of library problems in terms of general managerial concepts have already appeared in print. $^{2}$

The foregoing analysis of the administrative process is obviously fragmentary. At one end it neglects that reconciling of philosophy and expediency which we call policy making and at the other it ignores that balancing of results and excuses which we call measurement. The purpose of the statement was to illustrate the freshness of approach that occurs when one starts from outside the library in the objectives and experiences of administration. It is in the direction of general administrative principles and methods-from accounting to zoning - that the content of a course in genuine library administration can be found.

\section{Methods in Teaching Library Administra- tion}

Every teacher has moments when he understands Henry Adams' remark to Santayana: "It isn't really possible to teach anything." Many a day the instructor starts for his class thinking: I have only one or two propositions to convey today, and, if I had the gift of words or if the students had the gift of understanding, I could write the propositions on the blackboard in two dozen well-chosen words. Instead the instructor describes, explains, discusses, illustrates, cajoles-saying the same thing in ten different ways-and still only a fraction of the students really comprehend. Many students report that such concepts as unity of management and limited span of control did not come alive

2 Howard, Paul, "The Functions of Library Management." Library Quarterly 10:313-49, July 1940; McDiarmid, E. W., and McDiarmid, John. The Ad. ministration of the American Public Library. Chicago, American Library Association and the University of Illinois Press, 1943, 250p; Miles, Arnold, and Martin, Lowell. Public Administration and the $\mathrm{Li}$ brary. Chicago, University of Chicago Press, 194I, 3r 3 p. 
for them until they found themselves in situations where these conditions were lacking.

Misgivings of this nature are inevitable in teaching administration. The words and concepts in the field are not abstractions of reality which can be verified in concrete situations but are abstractions of experience. There is little point in learning the principles as dogma, for they are only guides to action and may actually be dangerous if one does not know when to violate them. There is even less point in committing the principles to memory because they lack close interrelation and one would not know which to apply in a given situation.

Visual devices are helpful in conveying certain parts of the field of administration. This applies not only to the physical artifacts of buildings and equipment but to some administrative methods and processes as well. Analytical motion pictures showing books passing through the acquisition and preparation divisions of libraries and their use in the service program would be effective in demonstrating the unity of the library's task if constant attention were given to the relationship of function and technique. The human factor in administration might be introduced into the classroom by motion pictures of actual personnel interviews and staff meetings in libraries.

Directed observation of libraries in operation may also be used to good purpose. This approach has its counterpart in the clinic of the medical school. Directed observation should be distinguished, on the one hand, from brief library visits by students, which readily become superficial in character, and, on the other hand, from practice work by students, which may have the effect of emphasizing the segmented job rather than the over-all process.

But the various improved methods beg the main question. There still remains the tendency for the classroom to become an exercise in intellectual irresponsibility. Even if the content is administrative rather than technical, it is likely to exist in a vacuum. Faced with administrative problems, students make offhand decisions which will never catch up with them. The brighter students delight in generalizing particular situations into theories, to which they will be slaves for the rest of their lives.

In this connection the case method of teaching library administration may have its place. This does not mean using working situations deductively as illustrations of points made or principles expounded-a technique now used widely. It means inductive use of case studies to lead the student to his own discovery of underlying principles-a kind of forcing of experience. Law schools use this approach almost exclusively; they do not give the student a definition of justice and then have him study cases for illustrative purposes, but they use cases as records of experience out of which the student builds his own concept of the law.

The Graduate Business School at Harvard has used the case method extensively in administrative instruction. The Harvard example underlines two requisites of this approach: complete and substantial cases are required, which may necessitate use of field workers to obtain all the facts and conditions in a case; and the instruction period is a lengthy one. Nonetheless, the method has the decided advantage of facilitating self-discovery on the part of a student, and in the end this may be the only effective way of teaching anything.

The case study approach is a step in the right direction. But if complete integration of the theoretical and practical aspects of education in administration is to be accomplished, the preparation of library administrators must be recognized as a joint 
responsibility of library schools and libraries, just as the preparation of doctors is the joint responsibility of medical schools and hospitals. A comprehensive program for training executives would start in the library school and end within the walls of libraries. To accomplish this, the former must revise their administration courses and also perhaps their curriculums, while the latter must provide an administrative career service within and between libraries.

This in no way relieves the library schools of the first responsibility; nor does it give license to the library administrators' particular brand of irresponsibility, which is to disparage the preparation of administrators in the classroom while making no provision to produce such individuals themselves.

\section{Placing the Teaching of Administration}

If library schools are to embark on a program of training administrators, a new series of questions immediately arises. Shall all students be trained as administrators? If not, who will select the "elite," and on what basis? Are first-year students able to handle general administrative material and, if not, does this mean a second year of education for administrators?

This carries the discussion into the general area of the library school curriculum. The fundamental problem of the library school curriculum is that, while it is basically a training program for imparting technical skills, it has graduate, professional, and administrative aspirations. Technical skill as used here does not refer to cataloging, reference, or other professional tasks as such. It refers to skills which require special training and presuppose normal agility and accuracy of mind but which do not require a general college education or professional judgment, either in learning or execution. Such skills are found in most courses in the library school curriculum. The circulation and order type of material in the administration course has already been mentioned. In cataloging such matters as physical format of cards, simple descriptive entry, and filing fall into this class, and in reference the use of various bibliographic tools and quick reference books belongs here. A surprising amount of time in the library school is devoted to training at this level.

Several schools have reasoned that the elementary character of the technical courses and the graduate quality of library students should permit a compressing of technical training into a shorter time span. The time saved is then devoted to new types of intellectual content, in new courses and additions to regular courses. This trend holds promise and indeed in some instances has progressed to the point where the content of education for librarianship is definitely at the graduate level. To date, however, it has not resulted in a new and integrated curriculum but in a dual curriculum made up of separate parts. Perhaps we are trying to create a professional or administrative program by making adjustments in a technical program-as though a medical school could be set up by adaptations in the training program for nurses or an engineering school by adaptations in the training program for draftsmen.

At this point in the discussion of the library school curriculum, the realist is likely to recall everyone to earth by citing the demands from libraries for skilled technicians. Such demands are perfectly natural. The hiring librarian has certain technical positions for which he pays good clerical salaries, and he turns to the training agencies for qualified candidates. Once he gets the technicians, he will identify individuals of unusual background and potentiality and by means of informal internship develop his top-flight professional 
and administrative personnel.

This situation outlines the basic problem of education for librarianship. The student prerequisites, the academic placement, and parts of the curriculum of the library school are at the professional level. Other parts of the curriculum, the usual native quality of recruits, the salaries for which graduates are hired, and the work they do when hired, are at the skilled technical level. The production of administrators, subject specialists, and guidance and organization librarians will occur more frequently in library schools at such time as the responsibility for training library technicians is deflated to its appropriate level in the academic scheme-perhaps in junior college terminal courses.

Any practical program for training administrators in library schools must fit into the present pattern, no matter what its peculiarities. If the prevailing library curriculum were entirely at the graduate level, it might be possible to start the preparation of administrators in the first-year school. The first-year student, who would specialize in administration in the same way that other students stress subject or guidance library work, would go out into a year of administrative internship in a library and then into a second year of education or into a minor administrative position. The question of whether youthful students at the first-year level can understand concepts of management confuses rather than clarifies the issue, for it fails to take account of differences in individuals. The person with definite administrative potentialities will profit from introductory administrative training at the postgraduate level in the same way that other persons with other potentialities will profit from training in organizing or in interpreting materials. At a comparable age, a law or medical student is approaching the end of his formal education and will stand before the bench or at the bedside at no more advanced years than the young librarian at his junior executive desk.

But there are several reasons why it would be a mistake to undertake to produce administrators within the framework of the first-year curriculum as constituted at present. As agencies for technical training, library schools naturally recruit young people interested in such training. They do not recruit young people as potential administrators, except in the case of rare individuals who consciously decide to acquire the technical training as a step along the prescribed road toward an administrative career. Moreover, the substance of the curriculum being technical in nature, any attempt to incorporate training for administration into it is likely to result in two inarticulated segments of education. Administrative content, like other new forms of content, can find a place in the first-year curriculum only by "muscling in" on the basic technical material.

This does not mean that the first-year curriculum should have no course called "library administration." As members of service institutions, library school graduates should understand the government and organization of those institutions and have a sense of financial and personnel conditions and problems which affect them as individual workers. This is needed for reasons of both morale and public relations. The technical worker also needs an understanding of how the whole organization works toward common purposes. A course in administration in the first-year curriculum can stress the relation of jobs to functions and thus counteract the segmented viewpoint that may result from specific courses. But the objective of a course at the first-year level would not be the development of administrative attitudes and judgment.

(Continued on page 345) 
it is better to use old cards when possible. This is particularly true if L.C. subject headings and added entries have been accepted in most cases.

Experience has shown that from the standpoints of speed and final appearance an electrical eraser is probably the most effective tool for removing the old call numbers from cards. A clerical assistant with a little training can take off such numbers at the rate of from two to five per minute. The final procedure should show a smooth surface at the spot on the card where the new call number is to be typed; otherwise, fingering by users of the card catalog will dim or remove the retyped figures and letters.

In recapitulation, three points may be made. The decision in regard to the order of reclassification should rest on the criterion of use, unless conditions are such that some other order cannot be avoided. In the disposal of new acquisitions, the user of the stacks must suffer somewhat by the recommendation that accessions be placed with the new classification rather than with the old numbers, until the whole class is rearranged. If the reclassification is planned definitely as a speedy process, an exception to this rule may be made. In regard to the various routines for carrying on the mechanical work of reclassification, the aim should always be the establishment of those activities which insure a free flow of material through the technical department. Such a procedure will reduce the costs of operation as well as give maximum service to users during the process.

\section{Shall Library Schools Teach Administration?}

\section{(Continued from page 340)}

Under the present scheme the real administrative program must be delegated to the second year of library training. At this level, some students are recruited for administrative potentialities, the curriculum has the requisites of time and flexibility, and the administrative content will be compatible with the professional and research content. The approach might well be in terms of the basic managerial principles and concepts mentioned earlier, built around the administrative process, and applied to libraries by means of adequate case studies.
For the present, this seems best placed in the second year of study. In the future, it may be just as appropriate in the first year; and, indeed, much of the administrative and professional material in the second year may eventually be found in the first year when the purely technical material is removed from that level. But, in either case, the library school is potentially able to supply the junior executives which the profession needs. We will move in that direction, both in content and method, once we decide actually to teach administration in the library school. 